\title{
Východokarpatské pomezí kultur v románovém cyklu Na wysokiej połoninie Stanisława Vincenze
}

\author{
Michal Przybylski (Brno)
}

\begin{abstract}
Abstrakt
Autor této studie se zabývá prínosem tvorby významného polského prozaika a esejisty minulého století Stanisława Vincenze (1888-1971) pro uchování tradiční lidové kultury Východních Karpat a zejména etnické skupiny Huculů. Článek se soustředí především na nejproslulejší Vincenzovo dílo, rozsáhlou (do češtiny dosud nepřeloženou) tetralogii Na wysokiej połoninie, ale věnuje se i dalším aspektům tohoto románového cyklu - pojednává mj. o časových a prostorových dimenzích zobrazeného huculského světa, složité genologické charakteristice díla a spojitostech s jinými autory (např. Jerzym Stempowským či Witem Tarnawským).
\end{abstract}

\section{Klíčová slova}

Stanisław Vincenz; Na wysokiej połoninie; Huculsko; Huculové; pohraničí kultur; Jerzy Stempowski; tradiční lidová kultura $v$ literatuře

\section{Abstract \\ The East Carpathian Borderlands of Cultures in Stanisław Vincenz's Novel-Cycle Na wysokiej połoninie (On the High Uplands)}

The author of the present study reflects upon the importace of Polish prosaist and essayist Stanisław Vincenz (1888-1971) for a preservation of East Carpathian traditional folk culture from the Hutsul region. The article primarily analyze Vincenz's most famous work, novel-cycle Na wysokiej połoninie (which is still untranslated in Czech). However, contribution is devoted to other aspects of Vincenz's tetralogy - the autor mentions specifically temporal and spatial dimensions of the Hutsul world, elements of many different genres in the novel-cycle or points of contact in work's of Jerzy Stempowski and Wit Tarnawski.

\section{Key words}

Stanisław Vincenz; Na wysokiej połoninie (On the High Uplands); Hutsul region; Hutsuls; borderlands of cultures; Jerzy Stempowski; traditional folk culture in literature

Tato studie vznikla na Masarykově univerzitě v rámci projektu Výzkum slovanského areálu: generační proměny číslo MUNI/A/1078/2018 podpořeného z prostředků účelové podpory na specifický vysokoškolský výzkum, kterou poskytlo MŠMT v roce 2019. 
Až do osmdesátých let minulého století bylo jméno polského prozaika a esejisty Stanisława Vincenze (1888-1971) známé jen nemnoha zasvěceným a o jeho monumentálním epickém cyklu Na wysokiej potoninie to platilo dvojnásob, nebot převážná část byla vydána teprve po autorově smrti. S delším časovým odstupem, když už můžeme na Vincenzovu tvorbu nahlížet jako na uzavřený celek, vychází stále zřetelněji najevo, že patřil k jedněm z nejoriginálnějších tvưrců polské literatury 20. století. Do jeho ústředního díla jako by se přetavil odkaz etnické a náboženské tolerance z počátků první Rzeczpospolity, tedy polsko-litevské šlechtické republiky, která fungovala od lublinské unie (1569) až do fatálního třetího dělení Polska v roce 1795.

Rod Vincenzů měl kořeny v jihofrancouzské Provence, ale po příchodu do východokarpatské oblasti se poměrně rychle polonizoval, když své nové sídlo nalezl v Słobodě Rungurské u Kolomyje, v oblasti Poláky označované jako Pokucie (název je odvozen od města Kuty v dnešním Ivano-Frankovském obvodu Ukrajiny), jež se rozkládá na horním toku řeky Prut a jejích přítoků, na dohled od Čornohory, nejvyššího horského pásma ukrajinských Karpat. Důkladného vzdělání hned v několika oborech se Stanisławu Vincenzovi postupně dostalo v Kolomyji, Lvově a Vídni, takže před druhou světovou válkou mohl aktivně podnikat v oblasti těžby a zpracování ropy, ale stále byl především filozofem, esejistou, redaktorem a překladatelem ovládajícím čtrnáct jazyků. Po vypuknutí války se v roce 1940 dostal do Mad’arska, kde pomáhal tamním Židům, za což si později vysloužit titul Spravedlivý mezi národy. Po válce žil v Německu, Francii a nakonec ve Švýcarsku. Zejména Vincenzovo letní sídlo ve francouzské alpské vesnici La Combe-de-Lancey se stalo doslova poutním místem pro jeho ještě nepříliš početné příznivce a obdivovatele, kteří jej s oblibou nazývali „lékařem lidských duši“, protože se i během vášnivých diskusí a sporů vždy dokázal povznést nad případné politické, etnické, sociální či náboženské rozdíly. ${ }^{1}$

Stanisław Vincenz byl ukázkovým příkladem opožděně debutujícího autora, nebot spisovatelem se stal až na prahu padesátky, na samém sklonku meziválečného období, kdy se ve společnosti i literatuře lavinovitě šířily katastrofické vize věštící další světový konflikt. Navzdory tomu však Vincenz předválečný katastrofismus, příznačný v té době pro řadu nejen polských autorů, automaticky nepřejímal, a to ani později a dalo by se říct v rozporu s vlastními prožitky z válečných let a vynucenému, a jak se ukázalo později trvalému, odchodu do exilu.

Než se zaměříme na Vincenzovo erbovní dílo, připomeňme krátce i jeho neméně inspirativní eseje a črty, které se formálně mnohdy přibližují tradici polského vypravěčského žánru gavenda, pokrývají však neobyčejně široké spektrum témat - dotýkají se kořenů a tradic evropské epiky, autorových oblíbenců Homéra a Danta, kulturních tradic různých regionů a zemí, díla J. Conrada či C. K. Norwida, židovské kultury, Lvova, Vídně, Dunaje, tradiční lidové kultury Karpat, fenoménu pastevectví jako činnosti po tisíciletí pozitivně utvářející lidskou civilizaci atd. Zbigniew Jarosiński trefně shrnul Vincenzovu esejistiku následujícími slovy: „[... jeho reflexe plynula pozvolným gavendovým proudem, erudovaná a soustreděná na svůj přdmět a svobodně přitom prekračovala hranice

1 Srovnej např. MIŁOSZ, Czesław: Zaczynajac od moich ulic. Wrocław: Wydawnictwo Dolnośląskie, 1990, s. 222-236. 
epoch a národnich prostředi."2 Soubory Vincenzových esejistických textů - Po stronie pamięci (1965), Dialogi z Sowietami (1966, česky 2002), Tematy żydowskie (1977), Z perspektywy podróży (1980) - vycházely výhradně v emigraci (v Paříži a v Londýně), doma v Polsku se mohly objevit až na počátku osmdesátých let.

Vincenzovo opus magnum - cyklus Na wysokiej potoninie. Obrazy, dumy i gawędy z Wierchowiny Huculskiej - je v první řadě projevem téměř biblické lásky k bližnímu, úcty k člověku jako konstruktivní síle, dílem, které se nevyhýbá klíčovým metafyzickým otázkám, zásadnímu a odvěkému střetu dobra a zla. Podotkněme, že ohromuje i svým objemem - v součtu totiž čítá přes dva tisíce stran (145 vydavatelských archů!), které vznikaly v průběhu více než čtyřiceti let. Autor ho rozčlenil do čtyř dílů, resp. na tři pásma (tak části sám označil), snad pro podobnost s horskými pásmy v jeho rodném kraji. První díl (současně první pásmo) nazvaný Prawda starowieku (Pravda starodávného věku) vyšel ve Varšavě v roce 1936 (později byl rozšířen), druhý díl Zwada (Svár) v roce 1970 v Londýně (stejně jako následující), vydání dalších dvou dílů se již za svého života Vincenz nedočkal - Listy z nieba (Dopisy z nebe), uzavírající druhé pásmo, se objevily v roce 1974 a závěrečný Barwinkowy wianek (Barvínkový věnec), představující třetí pásmo, teprve v roce 1979.

Ještě před válkou se Vincenz podílel na překladu tehdy poměrně populárního díla Panideal rakouského psychologa a filozofa Rudolfa Marii Holzapfla (1874-1930), který pocházel z krakovské židovské rodiny. A byl to právě on, kdo jej přesvědčil o univerzálních, nadčasových hodnotách tradiční lidové kultury a kdo vybídl svého překladatele, aby sepsal postupně se vytrácející huculské mýty a tradice. Sám Vincenz vnímal svůj cyklus především jako vyprávění o slovanské Atlantidě v srdci karpatských hor, jež nenávratně zmizela v rozbouřených vodách moderních dějin. Andrzej Kuśniewicz, další polský prozaik spjatý s východním pohraničím předválečného Polska (s tzv. Kresy), v předmluvě k prvnímu domácímu vydání cyklu poznamenal: „Vincenz pred zapomněním zachránil před léty, ještě v dětstvi a v mládí, zaslechnutá něči slova, př́běhy, legendy, uchovával a přenášel na papír to, co by bez něj navždy zmizelo. "3 Intenzivní zájem Vincenze o lidovou kulturu Huculů byl nepochybně umocněn magickou krásou vysokohorských polonin i nižších, zdánlivě nikde nekončících zalesněných kopců, průzračných horských řek a bystřin, opředených mnoha mýty, které už dříve fascinovaly tvůrce období romantismu a moderny (i jiných období) a jejichž tvůrčí inspiraci regionem Huculska ve své monografii uceleně zpracoval Jan Andrzej Choroszy. ${ }^{4}$

Ale nebyla to jen Vincenzova tvorba, jež uchovala pozdějším generacím mýty Huculska a východních Karpat. Specifické rysy této části předválečného polského východního pohraničí a tamní kultury se podařilo např. ve sbírkách Eseje dla Kasandry (1961) a Od Berdyczowa do Rzymu (1971) zachytit dalšímu z významných polských esejistů 20. století, Jerzymu Stempowskému (1894-1969), publikujícímu pod pseudonymem Paweł Hostowec, který se podobně jako Vincenz po skončení války už nikdy nevrátil do vlasti

2 JAROSIŃSKI, Zbigniew: Literatura lat 1945-1975. Warszawa: Wydawnictwo Naukowe PWN, 1996, s. 189, překlad M. P.

3 Viz Kuśniewiczova předmluva k VINCENZ, Stanisław: Na wysokiej potoninie. Pasmo I: Prawda starowieku. Warszawa: Instytut Wydawniczy PAX, 1980, s. 5-6, překlad M. P.

4 CHOROSZY, Jan Andrzej: Huculszczyzna w literaturze polskiej. Wrocław: vlastním nákladem, 1991. 
a natrvalo se usadil ve Švýcarsku. O konkrétních tematických paralelách a styčných plochách v esejistice obou autorů podrobněji pojednal Józef Olejniczak. ${ }^{5}$

Stempowski měl silně vyvinutou schopnost pronikat k podstatě a skrytému významu konkrétního místa či prostoru, dokázal vnímat a interpretovat svět prostřednictvím krajiny a jejího rázu, ale také se snažil objevovat způsob, jakým se dějiny vepsaly do tváře krajiny Kresů, do budov, zahrad, stromů, řek - Němenu, Západní Dviny, Vilije, Ikvy, Dněstru, a především v oblasti Huculska pramenícího Čeremoše, kterému připisoval největší magickou sílu. Podobně jako Vincenz, jenž mimochodem velkou část dětství prožil právě na březích Čeremoše v Krzyworówni/Kryvoryvni), čerpal ve své esejistice z antických kořenů evropské civilizace a vize Evropy jako unikátní mozaiky kultur. Tematizoval v ní ale i pocit soumraku a konce evropských dějin a prvořadého postavení evropského kontinentu ve světě, protože s notnou dávkou skepse pohlížel na možnost další existence křehké struktury, kterou znal ze svého kraje, protože mnohé vazby a vztahy byly za války nenávratně zpřetrhány „poryvy dějin utržených z řetězu“. I ve Stempowského esejistické tvorbě najdeme pozoruhodné relace z východních okrajů předválečného Polska, v nichž potvrzuje Vincenzovo stanovisko, že národnostní otázka tam byla ještě mnohem složitějšíi, než se zdálo, a že nestálost a proměnlivost etnické př́ślušnosti byla v tranzitivním prostoru Kresů na denním pořádku: „Wszystkie te odcienie narodowości i jezzyków znajdowaty się nadto cześciowo w stanie plynnym. Synowie Polaków stawali się nieraz Ukraincami, synowie Niemców i Francuzów - Polakami. W Odessie dziaty sie rzeczy niezwykte: Grecy stawaty sie Rosjanami, widziano Polaków wstępujacych do Sojuza Russkawo Naroda. Jeszcze dziwniejsze kombinacje powstawaty z matżeństw mieszanych. - Jeżeli Polak żeni się z Rosjanka - mawiat mój ojciec - dzieci ich sa zwykle Ukraińcami i Litwinami." ${ }^{* 6}$

Rovněž pozapomenutý kritik a prozaik Wit Tarnawski (1894-1988) se literárně projevil až poměrně pozdě, protože byl především lékařem, synem a nástupcem slavného doktora Apolinaryho Tarnawského, zakladatele tehdy módního sanatoria v Kosowě/Kosivě v jižním podhůří masivu Čornohory. Poněkud ve stínu autorovy kritické činnosti stála jeho vlastní tvorba, z níž zřejmě nejhodnotnější je sbírka povídek Ucieczka (Útěk, 1960). Titulní text má silně metaforický rozměr a využívá v literatuře známý a osvědčený kompoziční rámec údajně nalezeného rukopisu doplněného komentářem vydavatele. Děj se odehrává v prvních dnech září 1939, kdy se modravé nebe nad Huculskem stává „kulisou dramatu a život plynouci v zapadlé provincii v zaběhlých kolejich drogou, která otupuje ostražitost. "7 Hlavní hrdina utíká před válečnou zkázou vysoko do hor nad řekou Čeremoš. Prožívá tam intenzivní milostný cit, raduje se z harmonické krásy a idylického klidu nedotčené přírody, ale přesto nakonec umírá. Tarnawského povídky v sobě nesou výrazný otisk poetiky Stanisława Vincenze, i když podstatnou část podobných rysů jistě

5 OLEJNICZAK, Józef: Arkadia i małe ojczyzny: Vincenz - Stempowski - Wittlin - Mitosz. Kraków: Oficyna Literacka, 1992, s. 52-81.

6 STEMPOWSKI, Jerzy. W dolinie Dniestru. Listy o Ukrainie. Warszawa: LNB Wydawnictwo, 1993, s. 11, překlad M. P.

7 DANILEWICZ-ZIELIŃSKA, Maria: Szkice o literaturze emigracyjnej. Wrocław: Zakład Narodowy im. Ossolińskich, 1992, s. 290, překlad M. P. 
můžeme připsat svérázné autenticitě regionu, který byl oběma autorům společný nejen v životě, ale i v literární tvorbě.

Vraṫme se však k Vincenzově tetralogii $\mathrm{Na}$ wysokiej potoninie, kterou můžeme směle považovat za jedno z nejhodnotnější děl vzniklých na ukrajinsko-polském kulturním pomezí. Huculové jsou v autorově podání výjimečnou etnickou skupinou, zvláště jejich povaha, způsob života, starodávné obřady, zvyky a celá duchovní i materiální kultura jsou pro něj fenoménem, který si v sobě uchoval mnohé z předkřestanského období, konzervoval elementy archaického náboženského systému. Huculská mytologie a obřady byly pro Vincenze ideální matérií pro konfrontaci „pravdy starodávných věků s s,novými časy“. Na realizaci tohoto záměru se autor pečlivě připravoval četbou odborné i umělecké literatury (mj. inspirativního románu Mychajla Kocjubynského Stíny zapomenutých předků z roku 1912), ${ }^{8}$ tak každodenními rozhovory s Huculy, pravidelnou účastí na jejich svátcích spojených s ročním liturgickým a obřadním cyklem, studiem jejich folklóru a regionálních tradic.

Z genologického hlediska je nesnadné, ba téměř nemožné Vincenzovu tetralogii jednoznačně definovat a zařadit, nebot jde o mimořádně spletitý konglomerát literárních žánrů a forem s četnými časovými i dějovými digresemi. Podobně jako v koláží se v něm prolínají různé elementy: esej, gavenda, v níž vypravěč-„huculský Homér“ oslavuje mytický kout Východních Karpat, pastýřská či rodinná sága, ${ }^{9}$ epopej, ${ }^{10}$ sbírka pověstí, legend, bájí, apokryfů, veršů i popěvků, román, cyklus záměrných prozaických fragmentů, etnografický či religionistický traktát, memoáry. To vše společně vytváří mohutné ekumenické dílo propojující v sobě prvky katolicismu, uniatství, judaismu i lidové religiozity. Literární historik Jerzy Kwiatkowski cyklus přirovnal k tvorbě Stanisława Witkiewicze (1851-1915), protože „podobně jako ona uchovávala góralskou kulturu, tato - tesá do mramoru kulturu huculskou. Obě [Vincenzova i Witkiewiczova tvorba - pozn. M. P.] hledaji v primitivních formách života, mezi pastevci netknutými civilizaci a nivelizátorským kulturním univerzalizmem - svobodu“.11

Výchozím i závěrečným momentem celé tetralogie je svatba autorových rodičů v Kryvorivni v lůnu karpatských hor, v samotném srdci Huculska, v místech, kde se po staletí stýkaly vlivy a hranice Polska, Mad’arska (Uher) a Rumunska (Sedmihradska). Hrdiny Vincenzova cyklu se stali členové jeho vlastní rodiny, přátelé a známí, především ale krajina Východních Karpat a její rázovití obyvatelé - předně Huculové, kteř́i jsou v něm nazývaní autentickými jmény (Foka Szumejowy, Tanasij Urszega aj.), dále Židé, šlechtičtí hospodáři, rolníci, popi, kněží, rabíni, myslivci, krčmáři, vozkové, účastníci lednového

8 OŁDAKOWSKA-KUFLOWA, Maria: Na wysokiej potoninie Stanistawa Vincenza wobec Cieni zapomnianych przodków Mychajty Kociubyńskiego. In: Stanisław Vincenz: humanista XX wieku. Lublin: Towarzystwo Naukowe KUL, 2002, s. 201-218.

9 O roli pastevecké civilizace nejen u Vincenze píše Jerzy Stempowski ve své eseji Na wysokiej potoninie (viz STEMPOWSKI, Jerzy: $W$ dolinie Dniestru. Op. cit., s. 78-95).

10 Nejnověji o rysech epopeje v díle uvažuje např. PACZOSKA, Ewa: Między epopeja a saga. Na wysokiej potoninie Stanistawa Vincenza. In: Lekcje uważności. Moderniści i realizm. Warszawa: Wydawnictwo Naukowe PWN, 2018, s. 331-352.

11 KWIATKOWSKI, Jerzy: Literatura Dwudziestolecia. Warszawa: Państwowe Wydawnictwo Naukowe, 1990, s. 255, překlad M. P. 
povstání - nekonečně bohatá galerie postav, jež reprezentují národnostní, náboženskou i sociální skladbu tehdejší společnosti v regionu. V cyklu však nechybí ani postavy historické, legendární a mytologické: bájní obři Wielité, karpatští zbojníci (opryšci), tvůrce chasidismu Jisra'el ben Eliezer zvaný Ba'al Šem Tov, nechybí ani Bůh a Satan, dobří (Rachmanowie) a zlí (Syrojidy ${ }^{12}$ ) duchové. Na polskou svatbu, která je jedním ze středobodů celého cyklu, jak velí tradice, přicházejí zástupci všech rozličných stavů. Z kompozičního i symbolického hlediska tu nelze nevidět spatřovat vlivy národního dramatu Wesele Stanisława Wyspiańského, protože také u Vincenze je sbratření všech společenských vrstev na svatbě hlavním tématem, i když plní jen funkci narativního rámce celého díla.

První díl cyklu (Prawda starowieku) otevírá situace, kdy přítel hospodáře a hostitele, Hucul Foka Szumejowy, svolává svatebčany. Následuje vylíčení Fokova osudu, přičemž do vypravěčského toku jsou vnořeny etnografické popisy obydlí a karpatského pastevectví. Posléze se text obrací $\mathrm{k}$ huculské démonologii, černé a bílé magii, později k mytickým časům Huculska a ke vzpomínkám ${ }^{13}$ na př́iběhy slavných zbojníků, siláka Hołowacze, Dmytra Wasyluka a vůbec nejproslulejšího opryška Ołeksy Dobosze (Doboše, Oleksy Dovbuše). Následuje časový posun do poloviny 18. století, do dob soumraku východokarpatského zbojnictví a boje zbojníků s rakouským mocnářstvím i s Archijudou (Arcidáblem) - symbolickým duchem nesvobody. Již v prvním díle se také naplno projevuje fascinace autora orální tradicí a kultem živého slova, což v doslovu k dílu svého otce potvrdil syn Andrzej: „[...] byl předev̌̌ím člověkem živého slova a bezprostředniho styku s lidmi. Nebot tam, kde se nacházeli čtenári nebo posluchači, vznikaly jeho dialogy, skici, přednášky nebo cykly prédnášek. "14

Druhý díl tetralogie (Zwada) časově pokrývá šedesátá léta 19. století, kdy i do periferního Huculska nezadržitelně pronikají „nové časy“. Dochází k rozsáhlým odvodům branců do rakouské armády, plošnému mýcení panenských lesů, Foka Szumejowy zakládá spolek místních hospodářů, který není ušetřen vnitřních rozporů ani vnějších konfliktů s ambiciózním anglickým kapitálem, jenž si razí cestu i do odlehlého koutu střední Evropy. Před čtenářem vyvstává plastický obraz dobového civilizačního pokroku (který však pro Vincenze tak úplně pokrokem není, nebot má celou řadu stinných stránek, které narušují odvěký řád věcí a tím negují nemalou část výdobytků), namáhavé každodenní práce, ale v neposlední řadě i působivé panoráma krás karpatské horské přírody.

K výraznému zúžení časoprostoru dochází v třetí části (Listy z nieba), která se odehraje prakticky v průběhu jediného odpoledne na křtinách Fokovy dcery Hafijky. Výsledkem je přesto více než čtyři sta stran textu stylizovaného jako beseda u společného stolu. Text výrazně této části inklinuje $\mathrm{k}$ literatuře faktu a $\mathrm{v}$ detailních popisech vylíčených

12 O interpretaci př́běhu těchto postav jako paraboly násilné sovětizace společnosti viz GORZKOWICZ, Justyna: Traktat o wynaturzonej idei: Syrojidy Stanistawa Vincenza. In: Huculszczyzna w badaniach młodych naukowców. Red. M. Troll i A. Warchalska-Troll. Kraków: Oficyna Wydawnicza „Wierchy“. Centralny Ośrodek Turystyki Górskiej PTTK, 2011, s. 231-246.

13 O úloze vzpomínek a paměti v naraci celého cyklu viz rozsáhlou monografii KACZMAREK, Michał: Proza pamięci. Stanistawa Vincenze pamięć i narracja. Toruń: Wydawnictwo Adama Marszałek, 2009.

14 VINCENZ, Andrzej: Postowie. In: VINCENZ, Stanisław: Na wysokiej połoninie. Pasmo III: Barwinkowy wianek. Warszawa: Instytut Wydawniczy PAX, 1983, s. 550-564. 
událostí nabývá téměř dokumentárního charakteru, současně je však protkán mytickým výkladem světa a jeho komplexní sakrální vizí. ${ }^{15}$ Titul této části se odvolává mj. na tradici biblických apokryfů - z nebe přicházejí lidem dopisy a postupně kolují celým krajem.

Čtvrtý díl epopeje (Barwinkowy wianek) lze označit za soubor šlechtických příběhů a židovských legend, ale také za genealogii rodu Vincenzů. Hosté se přes nádherné hory Huculska sjíždějí na svatbu, cestou se zastavují v hostincích, rozmlouvají spolu a na svatbě donekonečna vyprávějí své příběhy, jimiž prostupují osobní vzpomínky autora, především z jeho dětství na přelomu 19. a 20. století. „Vincenzova meandrická, digresivni narace exponuje víceaspektový, mnohovrstevnatý charakter popisovaného světa," charakterizoval text literární vědec Andrzej Zawada. ${ }^{16}$

V jistém smyslu má tetralogie blízko k pojetí přírody i lidských osudi̊, které známe od některých mladopolských tvůrců. Navzdory tomu, že detailních rozdílů je řada, ${ }^{17}$ vyznačuje se Na wysokiej potoninie také jistou františkánskou pokorou a prostotou, využívá prvky mystických učení (v tomto případě chasidismus) a doplňuje to výjimečným citem pro vystižení genia loci. Krajinu Vincenz vnímá jako soubor unikátních míst, živých, oduševnělých a neopakovatelných, v nichž ústřední roli hraje člověk. ${ }^{18}$ Takovým místem je pro Vincenze mytizovaný prostor, kde pramení řeky Tisa, Seret, Prut a Čeremoš, idealizovaný huculský mikrosvět naplněný harmonií, mírem, souladem a pořádkem, kde má všechno své místo a čas. Nic se v něm nemůže odehrávat ani předčasně, ani přiliš pozdě, nebot’ vše vychází z přirozeného rytmu přírody, která je věčná a neomylná: „Zegarów ani wahadet dziejowych tam nie stychać. Cisza zagtębi górskich i leśnych ton, nawet wiatru silniejszego nie dopuszcza. Jedyne wahadta to rytmy szumów, pomiędzy szeptaniem kropel wiosennych zbudzonych spod lodów a letnia szumawa wód, to rytmy strzatów od trzaskania lodów wiosennych do letnich gromów. "19

V tetralogii Vincenz umně zachytil střet rozdílného vnímání času, rozpor „městského“ a „horského“ času, tedy diametrálně odlišných časů, v němž žijí obyvatelé měst a Huculové. Karpatská příroda si žije svým vlastním vnitřním rytmem, který má cyklickou podobou a vyznačuje se neustálými návraty. Podle tohoto času se zákonitě řídí i život Huculů a odráží specifické huculské „bezčasí“, žijí v přítomnosti chápané jako neustálé opakování minulosti, mají přesně vyměřený a rozvržený zpo̊sob života, v němž čas neodměřují ručičky hodin: „W gazdowskim życiu pośpiech niepotrzebny. Wszystko robi sie zawczasu, wszystko dzieje się na czas. Nikt się nie spóźni, bo woli wstać wcześnie, uporać się wcześnie, wyjść

15 MADYDA, Aleksander: Bóg - cztowiek - kosmos: o pogladach filozoficzno-religijnych Vincenza. In: Studia o Stanisławie Vincenzie. Lublin: Wydawnictwo KUL, 1994, s. 7-25.

16 ZAWADA, Andrzej: Literackie pótwiecze 1939-1989. Wrocław: Wydawnictwo Dolnośląskie, 2001, s. 193, překlad M. P.

17 OŁDAKOWSKA-KUFLOWA, Maria: Stanistaw Vincenz wobec dziedzictwa kultury. Lublin: Redakcja Wydawnictw KUL, 1997, s. 196-197.

18 KOLBUSZEWSKI, Jacek: Geografia Stanistawa Vincenza. In: Vincenz i krytycy: antologia tekstów. Wybór, wstęp i opracowanie Piotr Nowaczyński. Lublin: Wydawnictwo Uniwersytetu Marii Curie-Skłodowskiej, 2003, s. 251. Citovaný článek Kolbuszewského původně otištěn In: Świat Vincenza. Studia o życiu i twórczości Stanisława Vincenza. Wrocław: Oficyna Wydawnicza „Leopoldinum“, 1992, s. 251-258.

19 VINCENZ, Stanisław: Na wysokiej potoninie, Pasmo II: Ksiega 1, Zwada. Warszawa: Instytut Wydawniczy PAX, 1981, s. 9 . 
wcześnie, by zawsze mieć dość czasu. Tak byto dawniej. Odlegtości i podróży potonińskich nie obliczato się na godziny czy, kryj Boże, na minuty jak pociagi, lecz na dnie i tygodnie. Pośpiech to dziwactwo jakieś, a ciagty pośpiech, to śmiech, to choroba. " ${ }^{20}$ Huculové jsou si přesto vědomi, že velký svět kolem nich se řídí oním „druhým“ časem, který je jim ale zcela cizí, mají ho spojený s přistěhovalci z města, proto jej považují za čas městský, který je neslučitelný s jejich časem horským. Městský čas je časem lineárním, ubíhajícím neustále vpřed, kde včerejšek je minulostí, dnešek přítomností a zítřek budoucností. Huculové takové pojetí času neakceptují a ani mu nerozumějí. Jejich čas se nedělí na časové úseky, nepocitují časovou tíseň, čas prožívají ho výlučně ve svým myslích: „Poczucie czasu zatraca się: czas sie jakoś rozwiewa $i$ rozpyla, a nie śpieszy, jak jednowymiarowy szereg chwil $i$ godzin, uciekajacych jedna za druga, lecz rozdzwania się, jak chór kościelny, czasem się cofa, wdzięcznie przyciagajac, w tańcu rytmicznym i odwraca sie, jakby dziecko we śnie uśmiechnięte. To znów rozwija się, rozprościera, jak wachlarz i rozszerza po tąkach - nie czas to, lecz - fala wieczności. "21

Vincenz ale neopomíjí poukázat ani na mnohost lokálních časů, subjektivních a striktně přizpo̊sobených životnímu rytmu jednotlivých usedlostí v Huculsku, potřebám konkrétního jedince. Všechny ty jednotlivé časy plynou v jednom okamžiku zcela souměrně, jindy se křižují a protínají, vždy jsou však nablízku člověku, jeho záležitostem a domovu, jako by v nich bylo více lidskosti. Taková konstelace dodává huculským hrdinům cyklu pocit volnosti a svobody, nespoutanosti časem. Nezbytnou korekci čas od času provede příroda, s níž obyvatelé polonin žijí v obdivuhodné symbióze a shodě, není tedy divu, že právě příroda ovlivňuje jejich rozhodování a chování. Život ve shodě s rytmem př́rody v drsném kraji pro ně není břemenem, ale potěšením a darem od Boha.

Celý cyklus je ve své podstatě zrcadlem myšlení, hodnot a každodenního života huculských horalů a podle Piotra Nowaczyńského je v naprostém souladu s jejich vnímáním Boha a kosmu: „Pro Hucula je celý vesmír živým organismem, který umírá a oživá v rytmu čtvera ročnich obdobi. Je vyplněn bytostmi s vědomím a citem, se kterými je člověk blízce př́buzný a $k$ nimž musí zaujmout postoj lásky a bratrstvi - v př́padě zlých duchů zase respekt vưč jejich právưm. On totiž nestvořil pořádek světa. Jeho povinnosti je stát jedině na straně sil dobra, a ne zla. [...] Shrneme-li to, nejde o světonázor laický, ale náboženský, a nikoliv antropocentrický, ale kosmocentrický. "22

Huculové jsou přesvědčeni, že musejí žít podle „pravdy starodávných věků“, protože taková je vưle boží; to Bůh stvořil hory, díky nimž jsou blíže nebi, nebot’ právě nad jejich kouskem Karpat se otevírá nebe. A jelikož si Huculové učinili z Karpat své locum sacrum, tak musejí dodržovat ve svých horách i Bohem daný soulad a pořádek.

Tetralogii Na wysokiej potoninie můžeme vnímat i jako posvátnou knihu tří národů Poláků, Ukrajinců (resp. Rusínů, Huculů) a Židů. Jednoznačně k tomu přispěla vysoká míra idealizace, vynechání mnoha nepříliš pozitivních dobových reálií, mimo vypravěčovo zorné pole zůstávají různé národnostní a společenské třenice, pogromy, vzájemná netolerance, politické rozepře, ziskuchtivost, všechno, co ve skutečnosti často stavělo zá-

20 VINCENZ, Stanisław: Na wysokiej potoninie, Pasmo I: Prawda starowieku. Sejny: Pogranicze, 2002, s. 65.

21 Tamtéž, s. 59.

22 NOWACZYŃSKI, Piotr: O Prawdzie starowieku Vincenza: struktura - mit - idee. In: Studia o Stanisławie Vincenzie. Lublin: Wydawnictwo KUL, 1994, s. 75. 
stupce různých etnik, vyznání a sociálních statusů proti sobě. Celý cyklus je tak současně utopií i mýtem, zatímco pro jedny může být projevem slabosti, pro druhé se může stát oporou a posilou.

Avšak Vincenzovo dílo není výslovně adresováno a nenese poselství pouze třem výše zmíněným národům, má podle mého názoru i mnohem širší, přímo univerzální platnost. Vyzdvihuje význam aktu odpuštění, ale připomíná i nutnost smíriti se s existencí zla ve světě. Jedna z vedlejších dějových linií přenáší čtenáře do doby mytického konce času i světa a zachycuje konečné vykoupení Satana, motiv převzatý z chasidské tradice: Satan totiž stále je a zůstává synem Božím.

V díle Stanisława Vincenze (a platí to i pro in margine zmíněného Jerzyho Stempowského či Wita Tarnawského) vystupuje zřetelný obraz decentralizace a mnohotvárnosti polské předválečné kultury, přinášejí svědectví o již neexistujícím soužití jazykově, konfesně i etnicky zcela odlišných kultur s lidských světů, a to přesně v duchu názoru Wiesława Myśliwského (a v současném Polsku je jen málo povolanějších tvưrců, kteří by mohli komentovat otázku venkova a tradiční lidové kultury v literatuře), že „každá opravdová kultura se plně projeví teprve v okamžiku, kdy již odešla společně s formací, která ji stvorila. “233 Vincenzův monumentální „huculský epos"24 (byt není zcela ukončen) jako by se nehodil do doby, v níž vznikl. Stál mimo tehdejší hlavní myšlenkové a estetické proudy a na svůj vhodný okamžik musel čekat. Své přednosti odhaloval postupně - s plynutím času se výrazně projevila jeho schopnost postihnout v širší perspektivě zásadní kulturní a civilizační procesy a změny, které proběhly ve 20. století, a zdá se, že svou platnost zcela neztratil ani v 21. století.

\section{Literatura}

DANILEWICZ-ZIELIŃSKA, Maria: Szkice o literaturze emigracyjnej. Wrocław: Zakład Narodowy im. Ossolińskich, 1992.

GORZKOWICZ, Justyna: Traktat o wynaturzonej idei: Syrojidy Stanistawa Vincenza. In: Huculszczyzna w badaniach młodych naukowców. Red. M. Troll i A. Warchalska-Troll. Kraków: Oficyna Wydawnicza „Wierchy“. Centralny Ośrodek Turystyki Górskiej PTTK, 2011, s. 231-246.

CHOROSZY, Jan Andrzej: Huculszczyzna w literaturze polskiej. Wrocław: vlastním nákladem, 1991.

JAROSIŃSKI, Zbigniew: Literatura lat 1945-1975. Warszawa: Wydawnictwo Naukowe PWN, 1996.

KACZMAREK, Michał: Proza pamięci. Stanistawa Vincenze pamięć i narracja. Toruń: Wydawnictwo Adama Marszałek, 2009.

KOLBUSZEWSKI, Jacek: Geografia Stanistawa Vincenza. In: Vincenz i krytycy: antologia tekstów. Wybór, wstęp i opracowanie Piotr Nowaczyński. Lublin: Wydawnictwo Uniwersytetu Marii Curie-Skłodowskiej, 2003, s. 247-253.

KWIATKOWSKI, Jerzy: Literatura Dwudziestolecia. Warszawa: Państwowe Wydawnictwo Naukowe, 1990.

23 MYŚLIWSKI, Wiesław: Kres kultury chtopskiej. Twórczość LX, 2004, nr 4, s. 60, překlad M. P.

24 KACZMAREK, Michał: Proza pamięci. Stanistawa Vincenze pamięć i narracja. Toruń: Wydawnictwo Adama Marszałek, 2009, s. 224. 
MIŁOSZ, Czesław: Zaczynajac od moich ulic. Wrocław: Wydawnictwo Dolnośląskie, 1990.

MYŚLIWSKI, Wiesław: Kres kultury chtopskiej. Twórczość LX, 2004, nr 4, s. 53-61.

NOWACZYŃSKI, Piotr: O Prawdzie starowieku Vincenza: struktura - mit - idee. In: Studia o Stanisławie Vincenzie. Lublin: Wydawnictwo KUL, 1994.

OLEJNICZAK, Józef: Arkadia i mate ojczyzny: Vincenz - Stempowski - Wittlin - Mitosz. Kraków: Oficyna Literacka, 1992, s. 52-81.

OŁDAKOWSKA-KUFLOWA, Maria: Stanistaw Vincenz wobec dziedzictwa kultury. Lublin: Redakcja Wydawnictw KUL, 1997.

OŁDAKOWSKA-KUFLOWA, Maria: Na wysokiej potoninie Stanistawa Vincenza wobec Cieni zapomnianych przodków Mychajty Kociubyńskiego. In: Stanisław Vincenz: humanista XX wieku. Lublin: Towarzystwo Naukowe KUL, 2002, s. 201-218.

PACZOSKA, Ewa: Między epopeja a saga. Na wysokiej potoninie Stanistawa Vincenza. In: Lekcje uważności. Moderniści i realizm. Warszawa: Wydawnictwo Naukowe PWN, 2018, s. 331-352.

STEMPOWSKI, Jerzy: W dolinie Dniestru. Listy o Ukrainie. Warszawa: LNB Wydawnictwo, 1993.

Vincenz $i$ krytycy: antologia tekstów. Wybór, wstęp i opracowanie Piotr Nowaczyński. Lublin: Wydawnictwo Uniwersytetu Marii Curie-Skłodowskiej, 2003.

VINCENZ, Andrzej: Postowie. In: VINCENZ, Stanisław: Na wysokiej połoninie. Pasmo III: Barwinkowy wianek. Warszawa: Instytut Wydawniczy PAX, 1983, s. 550-564.

VINCENZ, Stanisław: Na wysokiej potoninie. Pasmo I: Prawda starowieku. Warszawa: Instytut Wydawniczy PAX, 1980.

VINCENZ, Stanisław: Na wysokiej potoninie. Pasmo I: Prawda starowieku. Sejny: Pogranicze, 2002.

VINCENZ, Stanisław: Na wysokiej potoninie. Pasmo II: Ksiega 1, Zwada. Warszawa: Instytut Wydawniczy PAX, 1981.

ZAWADA, Andrzej: Literackie pótwiecze 1939-1989. Wrocław: Wydawnictwo Dolnośląskie, 2001.

\section{Mgr. et Mgr. Michal Przybylski}

Ústav slavistiky

Filozofická fakulta, Masarykova univerzita

Arna Nováka 1, 60200 Brno, Česká republika

michalp@phil.muni.cz 